Buletin Ilmiah Math. Stat. dan Terapannya (Bimaster)

Volume 08, No. 4 (2019), hal 883 - 892.

\title{
BILANGAN INDEPENDENT DOMINATION PADA BEBERAPA GRAF
}

\author{
Lili Surai’ya, Evi Noviani, Fransiskus Fran
}

\begin{abstract}
INTISARI
Suatu himpunan simpul dari graf $G$ dikatakan himpunan domination jika semua simpul yang tidak berada di himpunan tersebut bertetangga dengan sedikitnya satu simpul di himpunan tersebut. Kardinalitas minimum dari himpunan domination disebut bilangan domination. Konsep himpunan domination terus berkembang salah satunya yaitu tentang himpunan independent domination. Simpul pada himpunan independent domination mendominasi simpul lain tetapi simpul pada himpunan tersebut tidak boleh saling bertetangga. Kardinalitas minimum dari himpunan independent domination yang dinotasikan dengan $i(G)$ disebut bilangan independent domination. Penelitian ini mengkaji tentang $i(G)$ pada beberapa graf yaitu graf cycle $C_{n}$, graf roda $W_{n}$, graf pizza $P z_{n}$, graf bunga matahari $S F_{n}$, graf antiprisma $A P_{n}$ dan graf prisma $A_{n}$. Graf pizza dan graf bunga matahari dibangun dari graf roda, graf roda dibangun dari graf cycle. Graf antiprisma dan graf prisma dibangun dari graf cycle. Berdasarkan analisis pada penelitian ini diketahui bahwa $i\left(C_{n}\right)=\left\lceil\frac{n}{3}\right\rceil$, $i\left(W_{n}\right)=1, \quad i\left(P z_{n}\right)=\left\lceil\frac{n}{3}\right\rceil+1, i\left(S F_{n}\right)=\left\lceil\frac{n}{2}\right\rceil, \quad i\left(A P_{n}\right)=\left\lceil\frac{2 n}{5}\right\rceil$, dan $i\left(A_{n}\right)$ untuk $n=4 k$ yaitu $\frac{n}{2}$, untuk $n=4 k+2$ yaitu $\frac{n}{2}+1$, untuk $n=4 k-1$ yaitu $\left\lceil\frac{n}{2}\right\rceil$, dan untuk $n=4 k+1$ yaitu $\left\lceil\frac{n}{2}\right\rceil+1, k \in \mathbb{N}$.
\end{abstract}

Kata Kunci : graf cycle, graf roda, graf pizza, graf bunga matahari, graf antiprisma, graf prisma.

\section{PENDAHULUAN}

Graf pertama kali diperkenalkan oleh seorang matematikawan Swiss bernama Leonhard Euler. Leonhard Euler berhasil mengungkap misteri teka-teki jembatan Königsberg pada tahun 1736. Misteri teka-teki yang berkaitan dengan jembatan Königsberg yaitu apakah seseorang dapat melakukan perjalanan berangkat dari suatu daratan ke daratan lain dengan melewati semua jembatan yang ada masing-masing tepat satu kali. Misteri teka-teki jembatan Königsberg tidak terpecahkan sampai munculnya pembuktian secara matematis dari Leonhard Euler. Leonhard Euler menggunakan bantuan sebuah graf sebagai model dengan melambangkan setiap daratan yang dipisahkan oleh Sungai Pregel sebagai simpul, sedangkan setiap jembatan dilambangkan sebagai sisi. Akhirnya Leonhard Euler sampai pada kesimpulan bahwa tidak ada rute perjalanan dari satu daratan kembali ke daratan tersebut dengan melewati semua jembatan masing-masing tepat satu kali [1]. Graf digunakan untuk mempresentasikan objek-objek diskrit dan hubungan dengan objek-objek tersebut. Suatu graf $G$ didefinisikan sebagai pasangan himpunan $(V, E)$, ditulis dengan notasi $G=(V, E)$, yang dalam himpunan ini $V$ adalah himpunan tidak kosong dari simpul-simpul (vertices atau node) dan $E$ adalah himpunan sisi (edge atau arcs) yang menghubungkan sepasang simpul [2].

Teori graf mengalami banyak perkembangan hingga saat ini. Salah satunya yaitu konsep independent domination. Konsep independent domination merupakan pengembangan dari konsep domination dan independent [3]. Himpunan domination dari sebuah graf $G$ merupakan himpunan $S$ subset dari $V$ dimana setiap simpul di $V-S$ bertetangga setidaknya dengan satu simpul di $S$. Bilangan domination yaitu kardinalitas minimum dari himpunan domination yang dinotasikan dengan $\gamma(G)$ [4]. Sedangkan himpunan independent dari graf $G$ adalah suatu himpunan simpul - simpul dengan tidak ada dua simpul dalam himpunan tersebut yang saling bertetangga [5]. Bilangan independent yaitu kardinalitas maksimum dari himpunan independent yang dinotasikan dengan $\alpha(G)$ [3]. Himpunan $S$ dari simpulsimpul graf $G$ dikatakan himpunan independent domination jika pada himpunan $S$ tidak ada dua simpul 
yang saling bertetangga dan setiap simpul di $V(G)$ bertetangga dengan simpul di himpunan $S$. Bilangan independent domination yaitu kardinalitas minimum dari himpunan independent domination yang dinotasikan sebagai $i(G)$.

Himpunan independent domination digunakan untuk mengatasi masalah lokasi pusat bantuan darurat. Graf $G$ digunakan untuk memodelkan sistem jalan dimana simpul-simpul dari $G$ yaitu persimpangan jalan dan sisi dari $G$ yaitu jalan yang menghubungkan persimpangan yang saling bertetangga. Permasalahan untuk menemukan beberapa lokasi titik pusat bantuan darurat sama dengan menentukan himpunan independent domination dari himpunan simpul pada graf $G$ dan kardinalitas dari solusi optimal permasalahan tersebut yaitu $i(G)[6]$.

Penelitian ini menganalisis bilangan independent domination pada graf cycle, graf roda, graf pizza, graf bunga matahari, graf antiprisma, dan graf prisma. Graf tersebut dipilih karena memiliki kesamaan satu dengan yang lainnya yaitu sama-sama dibangun dari graf cycle. Pada penelitian [7], telah dibahas bilangan independent domination pada graf helm, graf closed helm, graf gear, graf web. Jadi pada penelitian ini mencari formula bilangan independent domination pada graf cycle, graf roda, graf pizza, graf bunga matahari, graf antiprisma, dan graf prisma.

\section{BILANGAN INDEPENDENT DOMINATION}

Pada tahun 1862 De Jaenisch mencetuskan ide awal dari himpunan independent domination yang berasal dari permasalahan "dominasi ratu" pada permainan papancatur. Berge dan Ore pada tahun 1962 merumuskan teori awal mengenai independent domination, sedangkan bilangan independent domination yang dinotasikan dengan $i(G)$ diperkenalkan oleh Cockayne dan Hedetniemi pada tahun 1974-1977 [3].

Hubungan ketaksaaman antara bilangan independent domination dengan bilangan domination dan bilangan independent yaitu sebagai berikut,

Lemma 1 [3] Misal diberikan graf $G$ maka keterkaitan antara bilangan domination, bilangan independent domination, dan bilangan independent dapat ditulis sebagai berikut $\gamma(G) \leq i(G) \leq \alpha(G)$.

Contoh 2. Misalkan diberikan sebuah graf G

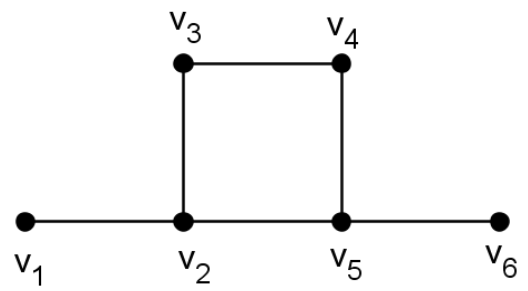

Gambar 1 Graf G

Pada Gambar 1 , simpul $v_{1}$ mendominasi simpul $v_{2}$. Simpul $v_{3}$ mendominasi simpul $v_{2}$ dan $v_{4}$, simpul $v_{5}$ mendominasi simpul $v_{2}, v_{4}, v_{6}$ serta simpul $v_{1}, v_{3}, v_{5}$ saling independent, sehingga dapat dipilih sebagai himpunan independent domination dari graf $G$ yaitu $\left\{v_{1}, v_{3}, v_{5}\right\}$. Selain itu, terdapat beberapa kemungkinan himpunan independent domination pada graf $G$ yaitu $\left\{v_{1}, v_{3}, v_{5}\right\},\left\{v_{1}, v_{3}, v_{6}\right\},\left\{v_{1}, v_{4}, v_{6}\right\}$, $\left\{v_{2}, v_{4}, v_{6}\right\}$. Bilangan independent domination dari graf $G$ tersebut yaitu 3. Simpul $v_{2}$ dan simpul $v_{5}$ mendominasi semua simpul pada graf $G$ sehingga himpunan domination pada graf $G$ yaitu $\left\{v_{2}, v_{5}\right\}$. Bilangan domination pada graf $G$ tersebut yaitu 2. Kemungkinan himpunan independent pada graf $G$ yaitu $\left\{v_{1}, v_{3}, v_{5}\right\},\left\{v_{1}, v_{3}, v_{6}\right\},\left\{v_{1}, v_{4}, v_{6}\right\},\left\{v_{2}, v_{4}, v_{6}\right\}$, dengan bilangan independent yaitu 3 . Secara ringkas himpunan serta bilangan independent domination pada graf $G$ dapat dilihat pada Tabel 1 berikut. 
Tabel 1 Independent domination pada graf $G$

\begin{tabular}{|c|c|c|c|c|c|}
\hline $\begin{array}{c}\text { Himpunan } \\
\text { Domination }\end{array}$ & $\gamma(G)$ & $\begin{array}{c}\text { Himpunan } \\
\text { Independent } \\
\text { Domination }\end{array}$ & $i(G)$ & $\begin{array}{c}\text { Himpunan } \\
\text { Independent }\end{array}$ & $\alpha(G)$ \\
\hline \multirow{3}{*}{$v_{2}, v_{5}$} & \multirow{2}{*}{2} & $\left\{v_{1}, v_{3}, v_{5}\right\}$ & 3 & $\left\{v_{1}, v_{3}, v_{5}\right\}$ & 3 \\
\cline { 3 - 6 } & & $\left\{v_{1}, v_{3}, v_{6}\right\}$ & 3 & $\left\{v_{1}, v_{3}, v_{6}\right\}$ & 3 \\
\cline { 3 - 6 } & $\left\{v_{1}, v_{4}, v_{6}\right\}$ & 3 & $\left\{v_{1}, v_{4}, v_{6}\right\}$ & 3 \\
\cline { 3 - 6 } & $\left\{v_{2}, v_{4}, v_{6}\right\}$ & 3 & $\left\{v_{2}, v_{4}, v_{6}\right\}$ & 3 \\
\hline
\end{tabular}

\section{Bilangan Independent Domination pada Graf Cycle $\boldsymbol{C}_{n}$}

Graf lingkaran (cycle graph) merupakan graf sederhana yang setiap simpulnya berderajat dua. Graf cycle dengan $n$ simpul dilambangkan dengan $C_{n}$ [8]. Bilangan domination dari graf cycle yaitu $\gamma\left(C_{n}\right)=\left[\frac{n}{3}\right]$. Bilangan independent domination pada graf cycle dengan $n \geq 3$ disajikan pada Proposisi 3 berikut,

Proposisi 3. [3] Bilangan independent domination pada graf cycle yaitu $i\left(C_{n}\right)=\left\lceil\frac{n}{3}\right\rceil$.

Bukti. Diberikan graf cycle dengan $n$ simpul $n \geq 3$. Setiap simpul pada graf cycle berderajat 2 . Himpunan simpul graf cycle yaitu $V\left(C_{n}\right)=\left\{v_{1}, v_{2}, \ldots, v_{n}\right\}$. Misalkan diambil sebarang $v_{i} \in V\left(C_{n}\right)$, dengan $i=1,2,3, \ldots, n$. Simpul $v_{i}$ mendominasi maksimal 2 simpul lainnya dan independent terhadap simpul lain. Satu diantara himpunan independent domination dari graf cycle dilambangkan dengan $A$ dan $B$ berikut :

$A=\left\{v_{1}, v_{4}, v_{7}, \ldots, v_{3}\left[\frac{n-1}{3}\right]_{-2}\right\} \bigcup\left\{v_{n-1}\right\}$ untuk $n=3 k+1, k \in \mathbb{N}$,

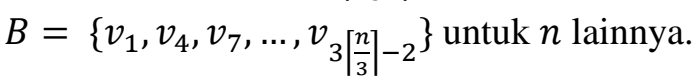

Bilangan independent domination dihitung dari banyaknya anggota pada himpunan $A$ dan $B$. Berdasarkan indeks pada himpunan $A$ dan $B$, simpul pertamanya dimulai dari $v_{1}$ dan beda 3 untuk simpul selanjutnya, pada himpunan $A$ indeks terbesarnya adalah $3\left\lceil\frac{n-1}{3}\right\rceil-2$, dan pada himpunan $B$ indeks terbesarnya adalah $3\left[\frac{n}{3}\right]-2$. Indeks pada himpunan $A$ dan himpunan $B$ dapat disusun menjadi suatu barisan aritmatika sebagai berikut :

$A^{\prime}=\left\{1,4,7, \ldots, 3\left[\frac{n-1}{3}\right\rceil-2\right\}$,

$B^{\prime}=\left\{1,4,7, \ldots, 3\left[\frac{n}{3}\right]-2\right\}$.

Banyaknya anggota himpunan tersebut dapat diperoleh menggunakan rumus barisan aritmatika dengan beda 3 dan suku pertama 1 sehingga pada himpunan $B$ suku ke $n$ yaitu $\left\lceil\frac{n}{3}\right\rceil$ dan pada himpunan $A$ suku ke $n$ yaitu $\left\lceil\frac{n-1}{3}\right\rceil+1$. Selanjutnya akan ditunjukan $\left\lceil\frac{n-1}{3}\right\rceil+1=\left\lceil\frac{n}{3}\right\rceil$. Karena pada himpunan $A n=3 k+$ 1 dengan $k \in \mathbb{N}$, sehingga

$$
\begin{aligned}
\left\lceil\frac{n-1}{3}\right\rceil+1 & =\left\lceil\frac{3 k+1-1}{3}\right\rceil+1=\left\lceil\frac{3 k}{3}\right\rceil+1 \\
& =\lceil k\rceil+1=k+1 \\
& =k+\left\lceil\frac{1}{3}\right\rceil=\left\lceil k+\frac{1}{3}\right\rceil \\
& =\left\lceil\frac{3 k+1}{3}\right\rceil=\left\lceil\frac{n}{3}\right\rceil
\end{aligned}
$$

Karena telah ditunjukan $\left\lceil\frac{n-1}{3}\right\rceil+1=\left\lceil\frac{n}{3}\right\rceil$, maka dapat disimpulkan bahwa banyaknya anggota himpunan independent domination tersebut yaitu $\left[\frac{n}{3}\right]$. Oleh karena himpunan independent domination tidak tunggal, maka bilangan independent domination haruslah memenuhi $i\left(C_{n}\right) \leq\left\lceil\frac{n}{3}\right\rceil$. Di lain pihak, 
berdasarkan Lemma 1 diperoleh $i\left(C_{n}\right) \geq\left\lceil\frac{n}{3}\right\rceil$. Jadi dapat disimpulkan bahwa bilangan independent domination pada graf cycle $i\left(C_{n}\right)=\left\lceil\frac{n}{3}\right\rceil$.

Contoh 4. Diberikan graf cycle $C_{4}$ seperti Gambar 2

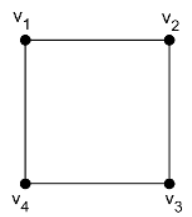

Gambar 2 Graf cycle $\boldsymbol{C}_{\mathbf{4}}$

Gambar 2, graf $C_{4}$ dengan himpunan simpul $V\left(C_{4}\right)=\left\{v_{1}, v_{2}, v_{3}, v_{4}\right\}$. Misalkan diambil simpul $v_{1}$, simpul tersebut mendominasi simpul $v_{2}$ dan $v_{4}$, tetapi independent dengan simpul $v_{3}$. Sehingga himpunan independent domination pada graf $C_{4}$ yaitu $\left\{v_{1}, v_{3}\right\}$. Bilangan independent domination dari graf cycle yaitu $i\left(C_{4}\right)=2$.

\section{Bilangan Independent Domination pada Graf Roda $W_{n}$}

Graf roda dengan $n+1$ simpul dilambangkan dengan $W_{n}$. Graf roda diperoleh dengan cara menambahkan satu simpul pada graf lingkaran $C_{n}$, dan menghubungkan simpul baru tersebut dengan semua simpul pada graf lingkaran tersebut [8]. Bilangan domination dari graf roda yaitu $\gamma\left(W_{n}\right)=1$. Bilangan independent domination pada graf roda dengan $n \geq 3$ disajikan pada Proposisi 5 berikut,

Proposisi 5. Bilangan independent domination pada graf roda yaitu $i\left(W_{n}\right)=1$ untuk $n \geq 3$.

Bukti. Diberikan graf roda dengan $n+1$ simpul dan $2 n$ sisi, Himpunan simpul graf roda $V\left(W_{n}\right)=$ $\left\{v_{0}, v_{1}, v_{2}, v_{3}, \ldots, v_{n}\right\}$. Simpul pusat $v_{0}$ pada graf roda berderajat $n$, dan simpul lainnya berderajat 3 . Karena simpul $v_{0}$ berderajat $n$ mengakibatkan simpul $v_{0}$ mendominasi semua simpul lainnya. Sehingga himpunan independent domination pada graf roda yaitu $\left\{v_{0}\right\}$. Oleh karena itu, bilangan independent domination graf roda yaitu 1. Jadi dapat disimpulkan bahwa bilangan independent domination pada graf $W_{n}$ yaitu 1.

Contoh 6. Diberikan graf roda $\mathrm{W}_{4}$ pada Gambar 3

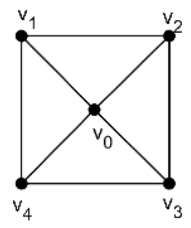

\section{Gambar 3 Graf roda $W_{4}$}

Gambar 3, graf roda $W_{4}$ dengan himpunan simpul $V\left(W_{4}\right)=\left\{v_{0}, v_{1}, v_{2}, v_{3}, v_{4}\right\}$. Pada graf $W_{4} \operatorname{simpul} v_{0}$ mendominasi semua simpul. Sehingga himpunan independent domination pada $W_{4}$ yaitu $\left\{v_{0}\right\}$. Bilangan independent domination pada graf roda yaitu $i\left(W_{4}\right)=1$.

\section{Bilangan Independent Domination pada Graf Pizza $P z_{n}$}

Graf pizza dengan $2 n+1$ simpul dinotasikan dengan $P z_{n}$. Graf pizza dibentuk oleh graf roda $W_{n}$ dengan $n+1$ simpul. Simpul pusat dari $W_{n}$ adalah simpul yang bertetangga dengan semua simpul lainnya. Setiap sisi yang bersisian dengan simpul pusat tersebut disebut dengan jari-jari (spoke) [9]. Bilangan domination dari graf pizza yaitu $\gamma\left(P z_{n}\right)=\left\lceil\frac{n}{3}\right\rceil+1$. Bilangan independent domination pada graf pizza disajikan pada Proposisi 7 sebagai berikut.

Proposisi 7. Bilangan independent domination pada graf pizza yaitu $i\left(P z_{n}\right)=\left\lceil\frac{n}{3}\right\rceil+1$, untuk $n \geq 3$. 
Bukti. Diberikan graf pizza $P z_{n}$ dengan $2 n+1$ simpul dan $3 n$ sisi. Graf pizza terdiri dari simpul $w_{i}$ yang berderajat tiga, simpul $v_{i}$ berderajat dua, dan simpul $c$ berderajat $n$ dengan $i=1,2,3, \ldots, n$. Himpunan simpul pada graf pizza yaitu $V\left(P z_{n}\right)=\left\{c, v_{1}, v_{2}, v_{3}, \ldots, v_{n}, w_{1}, w_{2}, w_{3}, \ldots, w_{n}\right\}$. Ambil sebarang $v_{i} \in V\left(P z_{n}\right)$, dengan $i=1,2,3, \ldots, n$. Simpul $w_{i}$ mendominsi tiga simpul lain dan independent terhadap simpul lain. Simpul $c$ mendominasi semua simpul $v_{i}$. Karena simpul $w_{1}, w_{2}, w_{3}, \ldots, w_{n}$ pada graf pizza dibangun dari graf cycle maka pola untuk himpunan independent domination-nya sama. Salah satu himpunan independent domination dari graf pizza dilambangkan dengan $A$ dan $B$ sebagai berikut : $A=\{c\} \cup\left\{w_{1}, w_{4}, w_{7}, \ldots, w_{3}\left[\frac{n-1}{3}\right]-2\right\} \bigcup\left\{w_{n-1}\right\}$ untuk $n=3 k+1, k \in \mathbb{N}$, $B=\{c\} \cup\left\{w_{1}, w_{4}, w_{7}, \ldots, w_{3}\left[\frac{n}{3}\right]-2\right\}$ untuk $n$ lainnya.

Bilangan independent domination dihitung dari banyaknya anggota pada himpunan $A$ dan $B$. Berdasarkan indeks pada himpunan tersebut, simpul pertamanya dimulai dari $w_{1}$ dan beda 3 untuk simpul selanjutnya, pada himpunan $A$ indeks terbesarnya adalah $3\left\lceil\frac{n-1}{3}\right\rceil-2$, dan pada himpunan $B$ indeks terbesarnya adalah $3\left[\frac{n}{3}\right]-2$. Indeks pada himpunan $A$ dan himpunan $B$ dapat disusun menjadi suatu barisan aritmatika sebagai berikut :

$A^{\prime}=\left\{1,4,7, \ldots, 3\left\lceil\frac{n-1}{3}\right\rceil-2\right\}$,

$B^{\prime}=\left\{1,4,7, \ldots, 3\left[\frac{n}{3}\right]-2\right\}$.

Banyaknya anggota himpunan tersebut dapat diperoleh menggunakan rumus barisan aritmatika dengan beda 3 dan suku pertama 1 sehingga pada banyaknya anggota pada himpunan $B$ yaitu $\left\lceil\frac{n}{3}\right\rceil+1$ dan banyaknya anggota pada himpunan $A$ yaitu $\left[\frac{n-1}{3}\right]+2$. Dengan menggunakan rumus aritmatika yang sama seperti pada proposisi 5 diperoleh $\left\lceil\frac{n-1}{3}\right\rceil+2=\left\lceil\frac{n}{3}\right\rceil+1$. Maka dapat disimpulkan bahwa banyaknya anggota himpunan independent domination dari graf pizza yaitu $\left\lceil\frac{n}{3}\right\rceil+1$. Oleh karena himpunan independent domination tidak tunggal, maka bilangan independent domination haruslah memenuhi $i\left(P z_{n}\right) \leq\left\lceil\frac{n}{3}\right\rceil+1$. Di lain pihak, berdasarkan Lemma 1 diperoleh $i\left(P z_{n}\right) \geq\left\lceil\frac{n}{3}\right\rceil+1$. Jadi dapat disimpulkan bahwa bilangan independent domination pada graf pizza $i\left(P z_{n}\right)=\left\lceil\frac{n}{3}\right\rceil+1$.

Contoh 8. Diberikan graf pizza $P z_{4}$ dengan Gambar 4

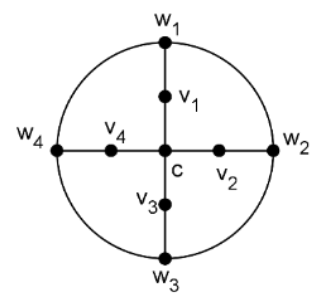

\section{Gambar 4 Graf pizza $P z_{\mathbf{4}}$}

Gambar 4, Graf $P z_{4}$ dengan himpunan simpul $V\left(P z_{4}\right)=\left\{c, v_{1}, v_{2}, v_{3}, v_{4}, w_{1}, w_{2}, w_{3}, w_{4}\right\}$. Misalkan diambil simpul $w_{1}$, simpul $w_{1}$ mendominasi simpul $v_{1}, w_{2}, w_{4}$ tetapi independent terhadap simpul $c, v_{1}, v_{2}, v_{3}$, dan $w_{3}$. Simpul $c$ mendominasi simpul $v_{1}, v_{2}$, dan $v_{3}$, independent terhadap simpul $w_{i}$, untuk $i=1,2,3, \ldots, n$, sehingga himpunan independent domination dari graf $P z_{4}$ adalah $\left\{c, w_{1}, w_{3}\right\}$. Bilangan independent domination pada graf pizza yaitu $i\left(P z_{4}\right)=3$.

\section{Bilangan Independent Domination pada Graf Bunga Matahari $\boldsymbol{S F}_{\boldsymbol{n}}$}

Sebuah graf roda dengan simpul pusat $c$ dengan $V\left(W_{n}\right)=\left\{c, v_{1}, v_{2}, v_{3}, \ldots, v_{n}\right\}$ serta $n$ simpul tambahan $W=\left\{w_{1}, w_{2}, w_{3}, \ldots, w_{n}\right\}$ dengan simpul $w_{i}$ yang dihubungkan dengan sisi ke simpul $v_{i}, v_{i+1}$ untuk $i=$ $1,2,3, \ldots, n$ dan simpul $w_{n}$ dihubungkan dengan sisi ke simpul $v_{n}, v_{1}$, disebut dengan graf bunga 
matahari yang dinotasikan dengan $S F_{n}$ untuk $n \geq 3$ [10]. Bilangan domination pada graf bunga matahari yaitu $\gamma\left(S F_{n}\right)=\left[\frac{n}{2}\right\rceil$. Bilangan independent domination pada graf bunga matahari disajikan pada Proposisi 9 berikut.

Proposisi 9. Bilangan independent domination pada graf bunga matahari yaitu $i\left(S F_{n}\right)=\left\lceil\frac{n}{2}\right\rceil$.

Bukti. Diberikan graf bunga matahari dengan $2 n+1$ simpul dan $4 n$ sisi. Simpul pada graf bunga matahari ada yang berderajat 5 yaitu simpul $v_{i}$ dan ada yang berderajat 2 yaitu simpul $w_{i}$. Himpunan simpul graf bunga matahari yaitu $V\left(S F_{n}\right)=\left\{c, v_{1}, v_{2}, v_{3}, \ldots, v_{n}, w_{1}, w_{2}, w_{3}, \ldots, w_{n}\right\}$. Ambil sebarang simpul $v_{i} \in V$, dengan $i=1,2,3, \ldots, n$ sehingga simpul $v_{i}$ akan mendominasi lima simpul lainnya dan independent terhadap simpul lainnya. Sedangkan untuk simpul $w_{i}$ hanya mendominasi dua simpul lainnya. Salah satu himpunan independent domination dari graf bunga matahari dilambangkan dengan $A$ dan $B$ seperti berikut :

$A=\left\{v_{1}, v_{3}, v_{5}, v_{7} \ldots, v_{2}\left[\frac{n}{2} \mid-1\right\}\right.$ untuk $n$ genap,

$B=\left\{v_{1}, v_{3}, v_{5}, v_{7} \ldots, v_{2}\left[\frac{n}{2}\right]-3\right\} \bigcup\left\{w_{n-1}\right\}$ untuk $n$ ganjil.

Bilangan independent domination dihitung dari banyaknya anggota pada himpunan $A$ dan $B$. Berdasarkan indeks pada himpunan tersebut, simpul pertamanya dimulai dari $v_{1}$ dan beda 2 untuk simpul selanjutnya, pada himpunan $A$ indeks terbesarnya adalah $2\left\lceil\frac{n}{2}\right\rceil-1$, dan pada himpunan $B$ indeks terbesarnya adalah $2\left\lceil\frac{n}{2}\right\rceil-3$. Indeks pada himpunan $A$ dan himpunan $B$ dapat disusun menjadi suatu barisan aritmatika sebagai berikut :

$A^{\prime}=\left\{1,3,5,7, \ldots, 2\left\lceil\frac{n}{2}\right\rceil-1\right\}$,

$B^{\prime}=\left\{1,3,5,7, \ldots, 2\left\lceil\frac{n}{2}\right\rceil-3\right\}$.

Banyaknya anggota himpunan tersebut dapat diperoleh dengan menggunakan rumus barisan aritmatika dengan beda 3 dan suku pertama 1 sehingga pada banyaknya anggota pada himpunan $A$ yaitu $\left\lceil\frac{n}{2}\right\rceil$ dan banyaknya anggota pada himpunan $B$ yaitu $\left[\frac{n}{2}\right]$. Sehingga banyaknya anggota himpunan independent domination yaitu $\left\lceil\frac{n}{2}\right\rceil$. Oleh karena himpunan independent domination tidak tunggal, maka bilangan independent domination haruslah memenuhi $i\left(S F_{n}\right) \leq\left\lceil\frac{n}{2}\right\rceil$. Di lain pihak, berdasarkan Lemma 1 diperoleh $i\left(C_{n}\right) \geq\left\lceil\frac{n}{2}\right\rceil$. Jadi dapat disimpulkan bahwa bilangan independent domination pada graf bunga matahari yaitu $i\left(S F_{n}\right)=\left\lceil\frac{n}{2}\right\rceil$.

Contoh 10. Diberikan graf bunga matahari $\mathrm{SF}_{4}$ dengan Gambar 5

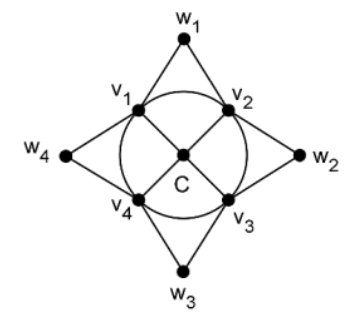

Gambar 5 Graf bunga matahari $S_{F_{4}}$

Gambar 5, Graf bunga matahari $S F_{4}$ dengan himpunan simpul $V\left(S F_{4}\right)=\left\{c, v_{1}, v_{2}, v_{3}, v_{4}, w_{1}\right.$, $\left.w_{2}, w_{3}, w_{4}\right\}$. Simpul $v_{1}$ mendominasi simpul $c, v_{2}, v_{4}, w_{1}, w_{4}$ tetapi independent terhadap simpul $v_{3}, w_{2}$ dan $w_{3}$. Simpul $v_{3}$ mendominasi simpul $w_{2}$ dan $w_{3}$, tetapi simpul $w_{2}$ dan $w_{3}$ saling independent. Sehingga himpunan independent domination pada graf $S F_{4}$ yaitu $\left\{v_{1}, v_{3}\right\}$. Bilangan independent domination pada graf bunga matahari yaitu $i\left(S_{4}\right)=2$. 


\section{Bilangan Independent Domination pada Graf Antiprisma $\boldsymbol{A} \boldsymbol{P}_{\boldsymbol{n}}$}

Graf antiprisma dinotasikan dengan $A P_{n}$. Graf antiprisma adalah graf dengan himpunan simpul $V\left(A P_{n}\right)=\left\{u_{i}, v_{i} \mid 1 \leq i \leq n\right\}$ dan himpunan sisi $E\left(A P_{n}\right)=\left\{u_{i} u_{i+1} \mid 1 \leq i \leq n-1\right\} \cup\left\{u_{n} u_{1}\right\} \cup$ $\left\{v_{i} v_{i+1} \mid 1 \leq i \leq n-1\right\} \cup\left\{v_{n} v_{1}\right\} \cup\left\{u_{i} v_{i} \mid 1 \leq i \leq n\right\} \cup\left\{u_{i} v_{i+1} \mid 1 \leq i \leq n-1\right\} \cup\left\{u_{n} v_{1}\right\}[11]$. Bilangan domination pada graf antiprisma yaitu $\gamma\left(A P_{n}\right)=\left\lceil\frac{2 n}{5}\right\rceil$. Bilangan independent domination pada graf antiprisma disajikan pada Proposisi 11 sebagai berikut.

Proposisi 11. Bilangan independent domination pada graf antiprisma yaitu $i\left(A P_{n}\right)=\left\lceil\frac{2 n}{5}\right\rceil$.

Bukti. Diberikan graf antiprisma $\left(A P_{n}\right)$ dengan $2 n$ simpul dan $4 n$ sisi. Simpul pada graf antiprisma berderajat empat. Himpunan simpul graf antiprisma yaitu $V\left(A P_{n}\right)=\left\{v_{1}, v_{2}, v_{3}, \ldots, v_{n}\right.$, $\left.u_{1}, u_{2}, u_{3}, \ldots, u_{n}\right\}$. Ambil sebarang $v_{i}$ atau $u_{i} \in V\left(A P_{n}\right)$, dengan $i=1,2,3, \ldots, n$ sehingga simpul $v_{i}$ atau $u_{i}$ mendominasi empat simpul dan independent terhadap simpul lainnya. Satu diantara himpunan independent domination dari graf antiprisma yaitu :

$A=\left\{v_{1}, u_{3}, v_{6}, u_{8}, v_{11}, \ldots, u_{5\left[\frac{n-3}{5}\right]-2}, v_{5}\left[\frac{n+1}{5}\right]-4\right\} \bigcup\left\{u_{n-1}\right\}$ untuk $n=5 k-2, k \in \mathbb{N}$,

$B=\left\{v_{1}, u_{3}, v_{6}, u_{8}, v_{11}, u_{13}, \ldots, v_{5}\left[\frac{n+1}{5}\right]-4, u_{5}\left[\frac{n-3}{5}\right]-2\right\}$ untuk $n=5 k-1, k \in \mathbb{N}$,

$C=\left\{v_{1}, u_{3}, v_{6}, u_{8}, v_{11}, u_{13}, \ldots, v_{5}\left[\frac{n}{5}\right]-4, u_{5}\left[\frac{n-3}{5}\right]-2\right\}$ untuk $n=5 k, k \in \mathbb{N}$,

$D=\left\{v_{1}, u_{3}, v_{6}, u_{8}, v_{11}, u_{13}, \ldots, v_{5}\left[\frac{n-1}{5}\right]-4, u_{5}\left[\frac{n-3}{5} \mid-2\right\} \cup\left\{v_{n-1}\right\}\right.$ untuk $n=5 k+1, k \in \mathbb{N}$,

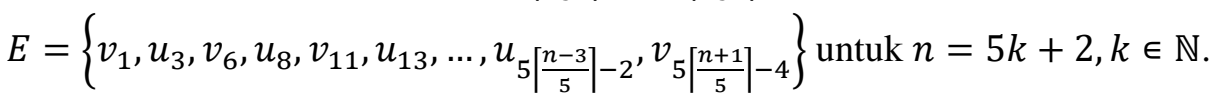

Bilangan independent domination dihitung dari banyak anggota pada himpunan tersebut. Berdasarkan indeks pada himpunan tersebut, simpul pertama $v_{i}$ dimulai dari $v_{1}$ dan beda 5 untuk simpul selanjutnya. Simpul pertama $u_{i}$ dimulai dari $u_{3}$ dan beda 5 untuk simpul selanjutnya. Pada himpunan $A$ simpul dengan indeks terbesarnya adalah $u_{5\left[\frac{n-3}{5}\right]-2}, v_{5\left[\frac{n+1}{5}\right]-4}$, pada himpunan $B$ simpul dengan indeks terbesarnya adalah $v_{5\left[\frac{n+1}{5}\right]-4}, u_{5\left[\frac{n-3}{5}\right]-2}$, pada himpunan $C$ simpul dengan indeks terbesarnya adalah $v_{5\left[\frac{n}{5} \mid-4\right.}, u_{5\left[\frac{n-3}{5}\right]-2}$, pada himpunan $D$ simpul dengan indeks terbesarnya adalah $v_{5\left[\frac{n-1}{5}\right]-4}, u_{5\left[\frac{n-3}{5}\right]-2}$, pada himpunan $E$ simpul dengan indeks terbesarnya adalah $u_{5}\left[\frac{n-3}{5}\right]-2, v_{5}\left[\frac{n+1}{5}\right]-4$. Pada himpunan tersebut indeks dari simpul $u$ dan simpul $v$ dapat disusun menjadi barisan aritmatika sebagai berikut :

$A_{v}{ }^{\prime}=\left\{1,6,11,16 \ldots, 5\left\lceil\frac{n+1}{5}\right\rceil-4\right\}, A_{u}^{\prime}=\left\{3,8,13,18, \ldots, 5\left\lceil\frac{n-3}{5}\right\rceil-2\right\}$,

$B_{v}{ }^{\prime}=\left\{1,6,11,16, \ldots, 5\left\lceil\frac{n+1}{5}\right\rceil-4\right\}, B_{u}^{\prime}=\left\{3,8,13,18, \ldots, 5\left\lceil\frac{n-3}{5}\right\rceil-2\right\}$,

$C_{v}{ }^{\prime}=\left\{1,6,11,16, \ldots, 5\left\lceil\frac{n}{5}\right\rceil-4\right\}, C_{u}^{\prime}=\left\{3,8,13,18, \ldots, 5\left\lceil\frac{n-3}{5}\right\rceil-2\right\}$,

$D_{v}{ }^{\prime}=\left\{1,6,11,16, \ldots, 5\left\lceil\frac{n-1}{5}\right\rceil-4\right\}, D_{u}^{\prime}=\left\{3,7,11,15, \ldots, 5\left\lceil\frac{n-3}{5}\right\rceil-2\right\}$,

$E_{v}{ }^{\prime}=\left\{1,6,11,16, \ldots, 5\left\lceil\frac{n+1}{5}\right\rceil-4\right\}, E_{u}^{\prime}=\left\{3,7,11,15, \ldots, 5\left\lceil\frac{n-3}{5}\right\rceil-2\right\}$.

Banyaknya anggota himpunan tersebut dapat diperoleh dengan menggunakan rumus barisan aritmatika sama seperti pembuktian proposisi 5. Pada barisan aritmatika ini dengan beda 5, suku pertama 1 dan 3 . Sehingga banyaknya anggota himpunan independent domination dari graf antiprisma yaitu $\left\lceil\frac{2 n}{5}\right\rceil$. Oleh karena himpunan independent domination tidak tunggal, maka bilangan independent domination haruslah memenuhi $i\left(A P_{n}\right) \leq\left\lceil\frac{2 n}{5}\right\rceil$. Di lain pihak, berdasarkan Lemma 1 diperoleh $i\left(A P_{n}\right) \geq\left\lceil\frac{2 n}{5}\right\rceil$. Jadi dapat disimpulkan bahwa bilangan independent domination pada graf antiprisma yaitu $i\left(A P_{n}\right)=\left\lceil\frac{2 n}{5}\right\rceil$. 
Contoh 12. Diberikan graf antiprisma $A P_{4}$ dengan Gambar 6

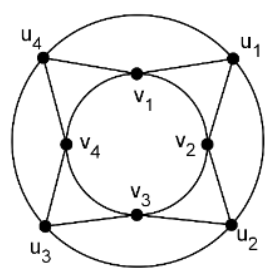

\section{Gambar 6 Graf antiprisma $\boldsymbol{A P}_{4}$}

Gambar 6, Graf antiprisma $A_{4}$ dengan himpunan simpul $V\left(A P_{4}\right)=\left\{v_{1}, v_{2}, v_{3}, v_{4}, u_{1}, u_{2}, u_{3}, u_{4}\right\}$. Misalkan diambil simpul $v_{1}$, simpul $v_{1}$ mendominasi simpul $v_{2}, v_{4}, u_{1}, u_{4}$ tetapi independent dengan $\operatorname{simpul} v_{3}, u_{2}, u_{3}$. Simpul $v_{3}$ mendominasi simpul $u_{2}$ dan $u_{3}$, sehingga himpunan independent domination dari graf $A P_{4}$ yaitu $\left\{v_{1}, v_{3}\right\}$. Bilangan independent domination pada graf antiprisma yaitu $i\left(A P_{4}\right)=2$.

\section{Bilangan Independent Domination pada Graf Prisma $A_{n}$}

Graf prisma $A_{n}$ adalah graf dengan himpunan simpul $V\left(A_{n}\right)=\left\{v_{0}, v_{1}, v_{2}, v_{3}, \ldots, v_{2 n-1}\right\}$ dan himpunan sisi $E\left(A_{n}\right)=\left\{v_{i} v_{i+1} \mid 0 \leq i \leq 2 n-2\right.$, untuk i genap $\} \cup\left\{v_{2 n-1} v_{1}\right\} \cup\left\{v_{i} v_{i+2} \mid 0 \leq i \leq\right.$ $2 n-3\} \cup\left\{v_{2 n-2} v_{0}\right\}[12]$. Bilangan domination pada graf prisma, $\gamma\left(A_{n}\right)=\left\{\begin{array}{l}\frac{n}{2}, n=4 k \\ \frac{n}{2}+1, n=4 k+2, k \in \mathbb{N} . \\ {\left[\frac{n}{2}\right], n=2 k+1}\end{array}\right.$ Bilangan independent domination pada graf prisma disajikan pada Proposisi 13 berikut.

Proposisi 13. Bilangan independent domination pada graf prisma yaitu

$$
i\left(A_{n}\right)=\left\{\begin{array}{l}
\frac{n}{2}, n=4 k \\
\frac{n}{2}+1, n=4 k+2 \\
\left\lceil\frac{n}{2}\right\rceil, n=4 k-1 \quad, k \in \mathbb{N} . \\
\left\lceil\frac{n}{2}\right\rceil+1, n=4 k+1
\end{array}\right.
$$

Bukti. Diberikan graf prisma $\left(A_{n}\right)$ dengan $2 n$ simpul dan $3 n$ sisi. Simpul pada graf prisma berderajat tiga. Himpunan simpul graf prisma yaitu $V\left(A_{n}\right)=\left\{v_{1}, v_{2}, v_{3}, \ldots, v_{n}, w_{1}, w_{2}, w_{3}, \ldots, w_{n}\right\}$. Ambil sebarang $v_{i}$ atau $w_{i} \in V\left(A_{n}\right)$, dengan $i=1,2,3, \ldots, n$ sehingga $v_{i}$ atau $w_{i}$ mendominasi tiga simpul lainnya dan independent terhapat simpul lainnya. Satu diantara himpunan independent domination dari graf prisma dilambangkan dengan $A, B, C$, dan $D$ sebagai berikut :

$A=\left\{v_{1}, w_{3}, v_{5}, w_{7}, v_{9}, \ldots, v_{2\left(\frac{n}{2}\right)-3}, w_{2\left(\frac{n}{2}\right)-1}\right\}$ untuk $n=4 k, k \in \mathbb{N}$,

$B=\left\{v_{1}, w_{3}, v_{5}, w_{7}, v_{9}, \ldots, w_{2\left(\frac{n}{2}+1\right)-5}, v_{2\left(\frac{n}{2}+1\right)-3}\right\} \cup\left\{w_{n}\right\}$ untuk $n=4 k+2, k \in \mathbb{N}$,

$C=\left\{v_{1}, w_{3}, v_{5}, w_{7}, v_{9}, w_{11}, \ldots, v_{2}\left(\left[\frac{n}{2}\right]\right)-3, w_{2\left(\left[\frac{n}{2}\right]\right)-1}\right\}$ untuk $n=4 k-1, k \in \mathbb{N}$,

$D=\left\{v_{1}, w_{3}, v_{5}, w_{7}, v_{9}, w_{11}, \ldots, v_{2\left(\left[\frac{n}{2}\right]+1\right)-7}, w_{2\left(\left[\frac{n}{2}+1\right]\right)-5}\right\} \cup\left\{v_{2\left(\left[\frac{n}{2}\right]+1\right)-4}, w_{n}\right\}$ untuk $n=4 k+1, k \in \mathbb{N}$.

Bilangan independent domination dihitung dari banyaknya anggota pada himpunan tersebut.

Berdasarkan indeks pada himpunan tersebut, simpul pertama $v_{i}$ dimulai dari $v_{1}$ dan beda 4 untuk simpul selanjutnya. Simpul pertama $w_{i}$ dimulai dari $w_{3}$ dan beda 4 untuk simpul selanjutnya. Pada himpunan $A$ simpul dengan indeks terbesarnya yaitu $v_{2\left(\frac{n}{2}\right)-3}, w_{2\left(\frac{n}{2}\right)-1}$. Pada himpunan $B$ simpul dengan indeks terbesarnya yaitu $w_{2\left(\frac{n}{2}+1\right)-5}, v_{2\left(\frac{n}{2}+1\right)-3}$. Pada himpunan $C$ simpul dengan indeks terbesarnya yaitu 
$v_{2\left(\left[\frac{n}{2}\right]\right)-3}, w_{2\left(\left[\frac{n}{2}\right]\right)-1} . \quad$ Pada himpunan $\quad D \quad$ simpul dengan indeks terbesarnya yaitu $v_{2\left(\left[\frac{n}{2}\right]+1\right)-7}, w_{2\left(\left[\frac{n}{2}+1\right]\right)-5}$. Pada himpunan tersebut indeks dari simpul $v$ dan simpul $w$ dapat disusun menjadi suatu barisan aritmatika sebagai berikut :

$A_{v}{ }^{\prime}=\left\{1,5,9,13 \ldots, 2\left(\frac{n}{2}\right)-3\right\}, \quad A_{w}{ }^{\prime}=\left\{3,7,11,15, \ldots, 2\left(\frac{n}{2}\right)-1\right\}$,

$B_{v}{ }^{\prime}=\left\{1,5,9,13, \ldots, 2\left(\frac{n}{2}+1\right)-3\right\}, \quad B_{w}{ }^{\prime}=\left\{3,7,11,15, \ldots, 2\left(\frac{n}{2}+1\right)-5\right\}$,

$C_{v}{ }^{\prime}=\left\{1,5,9,13 \ldots, 2\left\lceil\frac{n}{2}\right\rceil-3\right\}, \quad C_{w}{ }^{\prime}=\left\{3,7,11,15, \ldots, 2\left\lceil\frac{n}{2}\right\rceil-1\right\}$,

$D_{v}{ }^{\prime}=\left\{1,5,9,13, \ldots, 2\left(\left\lceil\frac{n}{2}\right\rceil+1\right)-7\right\}, D_{w}{ }^{\prime}=\left\{3,7,11,15, \ldots, 2\left(\left\lceil\frac{n}{2}+1\right\rceil\right)-5\right\}$.

Banyaknya anggota himpunan tersebut dapat diperoleh dengan menggunakan rumus barisan aritmatika dengan beda 4 dan suku pertama 1 atau 3, sehingga banyak anggota pada himpunan $A$ yaitu $\frac{n}{2}$, banyak anggota pada himpunan $B$ yaitu $\frac{n}{2}+1$, banyak anggota pada himpunan $C$ yaitu $\left\lceil\frac{n}{2}\right\rceil+1$ dan banyak anggota pada himpunan $D$ yaitu $\left\lceil\frac{n}{2}\right]+1$. Oleh karena himpunan independent domination tidak tunggal, maka bilangan independent domination haruslah memenuhi $i\left(A_{n}\right) \leq\left\{\begin{array}{l}\frac{n}{2}, n=4 k \\ \frac{n}{2}+1, n=4 k+2 \\ \left\lceil\frac{n}{2}\right\rceil, n=4 k-1 \quad, k \in \mathbb{N} \text {. Di lain } \\ \left\lceil\frac{n}{2}\right\rceil+1, n=4 k+1\end{array}\right.$ pihak berdasarkan Lemma 1 diperoleh $\gamma\left(A_{n}\right) \leq i\left(A_{n}\right)=\left\{\begin{array}{l}\frac{n}{2}, n=4 k \\ \frac{n}{2}+1, n=4 k+2 \\ \left\lceil\frac{n}{2}\right\rceil, n=4 k-1 \quad, k \in \mathbb{N} \text {. Dilihat dari } \\ \left\lceil\frac{n}{2}\right\rceil+1, n=4 k+1\end{array}\right.$ hubungan ketaksamaan tersebut untuk bilangan domination dan bilangan independent domination pada $A_{n}$ untuk $n$ ganjil terdapat perbedaan. Sehingga dibuktikan bilangan independent domination untuk $i\left(A_{n}, n=4 k+1\right)=\left\lceil\frac{n}{2}\right\rceil+1$. Andaikan $i\left(A_{n}, n=4 k+1\right)=\left(\left\lceil\frac{n}{2}\right\rceil+1\right)-1$, maka terdapat $\left\lceil\frac{n}{2}\right\rceil$ simpul yang merupakan kardinalitas minimum dari himpunan independent domination. Jika terdapat $\left\lceil\frac{n}{2}\right\rceil$ simpul yang dipilih sebarang, maka mengakibatkan paling sedikit ada 1 simpul yang tidak terambil, sehingga paling banyak ada 4 simpul yang tidak terdominasi. Hal ini bertentangan dengan definisi bilangan independent domination dengan kata lain $i\left(A_{n}, n=4 k+1\right)$ haruslah $\left\lceil\frac{n}{2}\right\rceil+1$. Jadi dapat disimpulkan bahwa bilangan independent domination dari graf prisma yaitu, $i\left(A_{n}\right)=\left\{\begin{array}{l}\frac{n}{2}, n=4 k \\ \frac{n}{2}+1, n=4 k+2 \\ {\left[\frac{n}{2}\right], n=4 k-1} \\ {\left[\frac{n}{2}\right]+1, n=4 k+1}\end{array}, k \in \mathbb{N}\right.$.

Contoh 9. Diberikan Gambar 7 graf prisma $A_{4}$

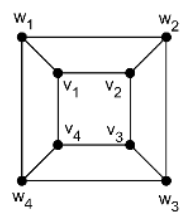

Gambar 7 Graf prisma Graf $A_{4}$ 
Gambar 7, graf prisma $A_{4}$ dengan $V\left(A_{4}\right)=\left\{v_{1}, v_{2}, v_{3}, v_{4}, w_{1}, w_{2}, w_{3}, w_{4}\right\}$. Misalkan diambil $v_{1}$, simpul $v_{1}$ mendominasi simpul $w_{1}, v_{2}, v_{4}$ tetapi independent dengan $v_{3}, w_{2}, w_{3}, w_{4}$. Diantara keempat simpul tersebut simpul $w_{3}$ mendominasi simpul $v_{3}, w_{2}$, dan $w_{4}$. Sehingga himpunan independent domination $A_{4}$ yaitu $\left\{v_{1}, w_{3}\right\}$. Bilangan independent domination dari graf prisma yaitu $i\left(A_{4}\right)=2$.

\section{KESIMPULAN}

Bilangan independent domination pada graf cycle, graf roda, graf pizza, graf bunga matahari, graf antiprisma dan graf prisma dapat diperoleh dari menentukan himpunan independent domination-nya terlebih dahulu, sehingga akan didapatkan bilangan independent domination. Pada penelitian ini diperoleh bilangan independent domination dari beberapa graf seperti $i\left(C_{n}\right)=\left[\frac{n}{3}\right], \quad i\left(W_{n}\right)=1$, $i\left(P z_{n}\right)=\left\lceil\frac{n}{3}\right\rceil+1, i\left(S F_{n}\right)=\left\lceil\frac{n}{2}\right\rceil, i\left(A P_{n}\right)=\left\lceil\frac{2 n}{5}\right\rceil$, dan $i\left(A_{n}\right)$ untuk $n=4 k$ yaitu $\frac{n}{2}$, untuk $n=4 k+2$ yaitu $\frac{n}{2}+1$, untuk $n=4 k-1$ yaitu $\left\lceil\frac{n}{2}\right\rceil$, dan untuk $n=4 k+1$ yaitu $\left\lceil\frac{n}{2}\right\rceil+1, k \in \mathbb{N}$.

\section{DAFTAR PUSTAKA}

[1] Ibrahim dan Mussafi NSM. Pengantar Kombinatorika \& Teori Graf. Yogyakarta: Graha Ilmu. 2012.

[2] Munir R. Matematika Diskrit Ed ke-3. Bandung: Teknik Informatika; 2010.

[3] Goddard W dan Henning MA. Independent Domination In Graphs: A Survey and Recent Results. Discrete Mathematics. 2013; 313:839-854.

[4] Ratnasari L, Surarso B, Harjito dan Maunah U. Bilangan Dominasi Persekitaran pada Graf Lengkap dan Graf Bipartit Lengkap. Jurnal Matematika. 2017; 20(1):20-26.

[5] Santoso B, Djuwandi dan Soelistyo RH. Bilangan Dominasi dan Bilangan Kebebasan Graf Bipartit Kubik. Jurnal Matematika. 2012; 15(1):12-16.

[6] Henning MA, Oellermann OR dan Swart, HC. The Diversity of Domination. Discrete Mathematics. 1996; 161:161-173.

[7] Vaidya SK dan Pandit RM. Independent Domination in Some Wheel Related Graphs. Applications and Applied Mathematics: An International Journal (AAM). 2016; 11(1):397-407.

[8] Puspasari A dan Irawanto B. Bilangan Radio pada Graf Gear. Jurnal Matematika. 2013; 16(1):2024.

[9] Nabila S dan Salman ANM. The Rainbow Connection Number of Origami Graphs and Pizza Graphs. Procedia Computer Science. 2015; 74:162-167.

[10] Amalia R dan Darmaji. Dimensi Partisi pada Graf Serupa Roda dengan Penambahan Anting. Jurnal Teknik Pomits. 2012; 1(1):1-6.

[11] Andira,D. Irene Y dan Hasanah I. Rainbow Connection Number dan Strong Rainbow Connection Number Pada Shackle Graf Antiprisma AP. Jurnal “LOG!K@”. 2018; 8(1):19-23.

[12] Lisitsyna MA. Perfect 3-Colorings of Prism and Möbius Ladder Graphs. Journal of Applied and Industrial Mathematics. 2013; 7(2):215-220.

LILI SURAI'YA $\quad$ : Jurusan Matematika FMIPA UNTAN, Pontianak lilisuraiyaa@gmail.com

EVI NOVIANI $\quad$ : Jurusan Matematika FMIPA UNTAN, Pontianak evi_noviani@math.untan.ac.id

FRANSISKUS FRAN : Jurusan Matematika FMIPA UNTAN, Pontianak fransiskusfran@math.untan.ac.id 